\title{
Viabilidade econômica da produção de biogás de dejetos suínos: um estudo de caso
}

\section{Economic feasibility of the treatment of swine manure in digesters: a case study}

\author{
Tatiane Machado da Silva Gomes ${ }^{1}$ \\ Augusta Pelinski Raiher ${ }^{2}$
}

\section{Resumo}

Este trabalho teve por objetivo verificar a viabilidade econômica do tratamento de dejetos de suínos em biodigestores. Especificamente, buscou-se quantificar a renda oriunda da produção de suínos e o quanto se agrega nela com a transformação dos dejetos nos biodigestores. Para isso, foram quantificados os custos, a receita e o lucro da suinocultura ex ante a implantação do biodigestor, parâmetros que serviram de base para a constatação da agregação de renda em cada situação formulada. Foram levantados dados sobre o custo de implantação do biodigestor e seu custo de manutenção, os quais foram utilizados na análise da viabilidade do investimento. Como resultado, foi constatado que a utilização dos biodigestores para o tratamento dos resíduos da suinocultura é uma alternativa viável economicamente, que além de minimizar os impactos ambientais, ainda fornece ao produtor agregação significativa de renda.

Palavras-chave: Biodigestores. Dejetos. Suinocultura. Viabilidade Econômica.

\section{Abstract}

This study aimed to verify the economic feasibility of the treatment of swine manure in digesters. Specifically, we sought to quantify the income from pig production

Graduada em Economia pela Universidade Estadual de Ponta Grossa. E-mail: tatianemsgomes@ gmail.com

2 Doutora em Economia pela Universidade Federal do Rio Grande do Sul. Prof. adjunta do departamento de economia da Universidade Estadual de Ponta Grasso. Endereço: Rua Cruz Machado, 1848, cep:84420-174, Castro, Paraná. Tel. 42-32324687. E-mail: apelinski@gmail. com 
and how much is added in the same with the transformation of waste in digesters. Thus, we quantified the costs, revenue and profit from swine ex ante deployment of biodigester, parameters that served as the basis for establishing the aggregate income in each situation formulated. Data on the cost of implementing the digester and its maintenance cost, which were used in the analysis of the viability of the investment. As a result, it was found that the use of digesters for swine waste treatment is a viable alternative economically, while minimizing environmental impacts, yet provides the producer with significant aggregation of income.

Keywords: Biodigestores. Waste. Hogs. Economic Viability.

\section{Introdução}

A suinocultura é uma atividade de grande destaque mundial. No Brasil e principalmente na região Sul ela desempenha um papel importante do ponto de vista socioeconômico. Juntos, os Estados de Santa Catarina, Rio Grande do Sul e Paraná são responsáveis por $65,9 \%$ da produção nacional (IBGE, 2012).

No caso paranaense, a produção está distribuída entre aproximadamente 136 mil produtores, dos quais apenas 30 mil estão efetivamente inseridos no mercado, sendo que os demais se referem às pequenas propriedades com produção destinada ao consumo familiar e atendimento ao comércio local. Desta forma, aproximadamente $78 \%$ da produção de carne suína do Paraná está localizada nas pequenas propriedades de agricultores familiares.

Contudo, ao se produzir a carne suína, um dos passivos ambientais gerados são os dejetos, os quais normalmente são manejados de maneira inadequada e acabam indo parar em rios e lençóis de água superficiais, gerando um grave problema ambiental, dada a sua grande capacidade de contaminação (260 vezes mais poluente, por exemplo, que o esgoto doméstico). Ainda, o metano - gás produzido a partir de matéria orgânica - é um dos gases causadores do efeito estufa, o que torna a questão mais preocupante do ponto de vista ambiental.

A preocupação com a destinação dos dejetos suínos não é recente, no entanto, vem tornando-se motivo de atenção para as 
autoridades ambientais devido à produção intensiva dessa cultura. Muitas são as técnicas existentes para a contenção e tratamento dos dejetos, como o seu uso para alimentos de outras espécies (peixes e gados, por exemplo) ou como adubo. No entanto, todas exigem um tratamento prévio dos dejetos, destacando que seu uso como adubo puro no solo pode acarretar sua degradação em longo prazo, por conter componentes como: fósforo, zinco, cobre e nitrogênio, os quais exercem ação deteriorante ao se transformarem em nitrato. Uma alternativa muito utilizada é a lagoa de contenção, porém esta deve ser impermeabilizada corretamente e, mesmo assim, não evita o lançamento de metano na atmosfera.

Além desses, existem outros meios de diminuir os impactos ambientais gerados pela suinocultura, como, por exemplo, a centrifugação e técnicas de tratamento químico, mas quase todos requerem investimentos com produtos e equipamentos que não trazem retorno financeiro direto ao produtor e que, por esse motivo, acabam sendo pouco utilizados.

O uso de biodigestor anaeróbico é uma alternativa de contenção e tratamento muito citada pelos autores da área, por se tratar de uma técnica que, além de minimizar o problema ambiental, ainda gera um subproduto - o biogás -, o qual pode ser transformado em energia elétrica, sendo usado na propriedade ou até mesmo vendido. O resíduo resultante do biodigestor anaeróbico pode ser utilizado como fertilizante, diminuindo custos ao produtor e mitigando o problema ambiental (se aplicado de forma racional).

Neste sentido, considerando a suinocultura uma atividade importante para a economia paranaense e que sua execução gera um passivo ambiental (dejetos) que precisa ser trabalhado, justifica-se este trabalho, que tem por objetivo analisar a viabilidade econômica da produção de biogás de dejetos suínos. Especificamente, busca-se: quantificar a renda oriunda da produção de suínos e quanto se agrega na mesma com a transformação dos dejetos nos biodigestores; identificar quais os investimentos necessários para a produção de biogás advindo 
dos dejetos; mensurar a renda proveniente da produção de biogás de dejetos suínos; e calcular a viabilidade econômica da transformação dos dejetos suínos em biodigestores.

Para isso, o trabalho está divido em cinco seções, incluindo esta. Na segunda, tem-se a concepção teórica acerca das energias renováveis, com destaque para o biogás de dejetos. Na sequência, são apresentados os elementos metodológicos por meio dos quais se auferiram os resultados. Na quarta seção é apresentada a análise, contendo a viabilidade econômica da implantação dos biodigestores, considerando diferentes cenários. Por fim, têm-se as considerações finais.

\section{Energias renováveis}

A energia está em toda parte, no interior do planeta, na luz do sol que o banha, na força da água dos rios, nos resíduos orgânicos descartados, dentre muitas outras fontes naturais renováveis.

De acordo com Waliesiewicz (2007), até 250 anos atrás, toda energia utilizada era natural. Animais puxavam arados, moinhos de vento trituravam grãos e a maior força motora da sociedade eram os músculos humanos, que hoje contribuem com menos de $1 \%$ do trabalho realizado nos países desenvolvidos. Cada vez mais, a humanidade se torna dependente de combustíveis fósseis, como o carvão e o petróleo. Durante décadas, esse tipo de combustível foi considerado inesgotável, contudo as guerras e as crises políticas revelaram a fragilidade das fontes de combustíveis e hoje a sociedade está mais cautelosa com relação a este assunto.

Apesar de se conhecer várias fontes renováveis de energia, continua-se a depender dos combustíveis fósseis por questão de comodidade, preço e questões políticas. No entanto, a grande dificuldade encontrada pelos que defendem a utilização das energias renováveis, as quais se têm em abundância no planeta, é encontrar uma forma de captá-la em grande escala, sem causar impactos na natureza. 
Walisiewcz (2007) considera a tecnologia utilizada para obter energia da água a mais desenvolvida atualmente e, ao mesmo tempo, a mais antiga de todas as fontes consideradas renováveis. Consideramse os engenhos de água, utilizados para mover moinhos moedores de grãos há três mil anos, os precursores das hidrelétricas que hoje são responsáveis pela geração de $19 \%$ da eletricidade consumida mundialmente, com uma eficácia de 90\%. A geração de energia em hidrelétricas baseia-se em princípios simples, em que as turbinas retiram energia da água do rio, acionando geradores elétricos. Porém, devese levar em conta o fato de que quando hidrelétricas são construídas em áreas mais planificadas, há um grande prejuízo ambiental devido às áreas que acabam alagadas pelas barragens.

Aenergia eólica é um dos melhores exemplos de energia renovável, pois além de o vento ser um dos recursos mais abundantes no mundo, ainda há o fato de que hoje em dia é mais barato gerar eletricidade com o vento do que com usinas nucleares ou movidas a carvão. Existem aproximadamente 20 mil turbinas eólicas gerando energia em alta escala no mundo todo. Este sistema é composto por duas ou três pás parecidas com asas, ligadas a um eixo horizontal que aciona um gerador elétrico. Todo o conjunto de pás se move na direção do vento, obtendo, assim, a máxima conversão de força.

Outras formas de energias renováveis que estão recebendo mais atenção ultimamente são os biocombustíveis, que são combustíveis de origem biológica, não fóssil, e a biomassa, fonte de energia limpa derivada de materiais orgânicos, da qual é obtido o biogás.

\subsection{Biogás}

O biogás é um biocombustível gasoso, inflamável, com alto conteúdo energético e muito semelhante ao gás natural (encontrado em jazidas subterrâneas). É composto, principalmente, por gás metano ( $\mathrm{CH} 4)$, que representa entre $55 \%$ e $70 \%$ do volume de gás produzido, e dióxido de carbono (CO2), presente em $30 \%$ a $45 \%$ do volume total (NOGUEIRA, 1986). Segundo Silva (1983), o metano é mais leve que 
o ar, não tem cheiro, cor ou sabor, mas os outros gases presentes na composição do biogás garantem um leve odor desagradável.

O biogás é obtido através do processo de biodigestão anaeróbia de matéria orgânica, na qual bactérias agem em um ambiente de ausência de oxigênio com $\mathrm{PH}$, temperatura, teor de umidade e nutrientes balanceados, fracionando compostos complexos para produzir um gás combustível (SILVA, 1983).

Sendo uma fonte higiênica e eficiente de energia, o biogás pode substituir combustíveis advindos de fontes não renováveis, como o gás natural e gás liquefeito de petróleo (GLP), destacando que sua chama não deixa resíduos e não desprende fumaça. Silva (1983, p. 15) ressalta que:

No emprego do biogás como combustível, deve-se estabelecer entre este e o ar uma relação que permita a combustão integral. Quando esta se dá, a chama é forte, de coloração azul-clara e o gás emite um assobio. Se a chama tremer, há insuficiência de ar e combustão incompleta. Se for curta, amarela e brilhar fracamente, indica biogás insuficiente e ar em excesso.

No entanto, Silva (1983) lembra que seu poder calorífico varia de acordo com a quantidade de metano presente no gás, portanto, quanto maior for a quantidade de metano, maior será o poder calorífico do biogás, gerando em média $5.500 \mathrm{Kcal}$, destacando que cada metro cúbico de biogás equivale a aproximadamente 0,45 Kg de GLP (gás de cozinha) ou $1,5 \mathrm{Kg}$ de lenha.

A biodigestão anaeróbia pode ocorrer de maneira natural, em aterros sanitários e esterco animal, por exemplo, ou pode-se utilizar de biodigestores anaeróbios (reatores biológicos) para a produção. A matéria utilizada para alimentar os biodigestores é a biomassa, "definida como qualquer material que tem a propriedade de se decompor por efeito biológico" (COLDEBELLA, 2006, p. 1), ou seja, são essencialmente de origem orgânica. Desta forma, assim como na produção natural, podem ser utilizados restos de alimentos, efluentes industriais com carga orgânica elevada, capim e dejetos de animais, dentre outros. 
"O uso de biodigestores para o tratamento principalmente de dejetos de animais é amplamente disseminado em todo o mundo, com plantas tanto em países desenvolvidos, quanto em países em desenvolvimento" (ZANETTE, 2009, p. 12). Mas, nos tempos atuais, os biodigestores são muito utilizados em países da Europa.

Nogueira (1986) argumenta que a produção de gás combustível a partir de resíduos orgânicos não é um processo novo, pois, no século XVIII, Alessandro Volta, na Itália, havia constatado a presença de metano no gás dos pântanos. No entanto, de acordo com Silva (1983), o primeiro biodigestor entrou em funcionamento apenas em 1900, em Bombaim, na Índia, e se popularizou a partir de 1939 neste país. A utilização mais intensa deu-se na China a partir de 1958, onde o modelo Indiano foi aprimorado e adaptado ao clima local.

Não existe um tipo ideal de biodigestor. Existem diversas modelos e maneiras diferentes de construção e o produtor deve conhecê-los para melhor atender ao conjunto de condições e necessidades. Os principais grupos de complexidade crescente são: digestores batelada, tanques sépticos, digestores rurais, digestores de grande porte, filtros anaeróbios e biodigestores em estado experimental. Hoje, existem vários modelos aprimorados com novas tecnologias e formas de construção diferentes, porém todos com o mesmo objetivo, que é o de maximizar e tornar viável a produção do biogás.

\section{- Biogás de dejetos suínos}

Conforme descrito anteriormente, o biogás pode ser produzido a partir de qualquer resíduo ou biomassa residual em estado líquido ou pastoso, que são resíduos e efluentes orgânicos, industriais, dejetos da produção de animal e os resíduos sólidos provenientes do beneficiamento da produção agrícola ou mesmo de lavouras especificamente plantadas para fins energéticos.

Considerando o potencial que a suinocultura brasileira vem demonstrando nos últimos anos e o fato dos dejetos e resíduos desta 
cultura serem fontes poluidoras do meio ambiente, a utilização dos biodigestores para a produção do biogás mostra-se uma alternativa para minimizar os impactos ambientais.

Diesel (2002) cita que, no processo de biodigestão anaeróbia, o potencial de destruição de microrganismos entéricos, que são de importância para a saúde pública, chega a ser de $100 \%$ no caso dos cistos de parasitos e da mycobacteriuntuberculosis, destruindo também mais de $98 \%$ da salmonela typhosa e do poliovirus, e ainda reduz em até $90 \%$ a carga orgânica, além de eliminar o mau cheiro do resíduo.

Contudo, a biodigestão anaeróbia, assim como outras técnicas de tratamento dos dejetos, não elimina totalmente o poder poluente da suinocultura e, segundo Nogueira (1986), o efluente dos sistemas anaeróbios pode ser agente poluidor, entretanto grande parte da matéria orgânica é eliminada e a capacidade poluente é bastante minimizada. De acordo com Diesel (2002), se o tempo de digestão for de 25 a 30 dias, a redução do potencial de polução é superior a $90 \%$. Em alguns casos, o material que sobra no biodigestor anaeróbio pode sofrer outro tratamento, reduzindo ao máximo a carga poluidora.

Deve-se considerar que a capacidade de poluição é reduzida o suficiente para o efluente poder ser utilizado como biofertilizante seguro. A possibilidade da utilização do resíduo do biodigestor como fertilizante de qualidade se deve à diminuição de teor de gás carbônico e, consequentemente, ao aumento do nitrogênio, o que melhora as condições do material para o uso agrícola, além de tal processo reduzir o odor desse resíduo, tornando-o totalmente inofensivo. Além disso, ele pode ser aplicado em pastagens e plantações em desenvolvimento sem correr o risco de queimá-las e deixar mau cheiro no ar.

Desta forma, este biofertilizante se torna mais uma fonte para a redução de custos ao produtor e consequente agregação de renda, pois a grande maioria dos suinocultores paranaenses tem a agricultura como atividade complementar em suas fazendas ou sítios. No entanto, destaca-se a necessidade de se fazer previamente um estudo acerca do solo, para não se aplicar em excesso esse biofertilizante, além de 
ser necessário também que seja feita uma análise a fim de constatar a quantidade de nutrientes presentes por $\mathrm{m}^{3}$ de efluente do biodigestor, pois Diesel (2002) afirma que a utilização do biofertilizante só é viável economicamente se a concentração de nutrientes no efluente for superior a $5 \mathrm{Kg} / \mathrm{m}^{3}$.

A utilização dos biodigestores é uma técnica que vem sendo difundida no Brasil pelas autoridades (ainda que de uma forma bastante tímida), com o objetivo de apresentar uma alternativa aos suinocultores quanto ao manejo dos dejetos que, concomitantemente, pode trazer retornos econômicos, haja vista as possibilidades de agregação de renda e redução dos impactos ambientais.

No meio rural, o biogás pode trazer grandes benefícios ao produtor ao ser utilizado para a geração de energia elétrica e, como energia térmica, por exemplo, nas instalações de animais sensíveis ao frio e em estufas de produção vegetal.

Coldebella (2006), em seu estudo de caso, aborda a viabilidade do uso do biogás produzido a partir dos dejetos da bovinocultura e da suinocultura, argumentando que o uso de biodigestores em propriedades rurais, além de ser um excelente tratamento dos resíduos gerados pelas atividades do agronegócio, torna-se economicamente viável se o biogás e o biofertilizante forem utilizados adequadamente. $O$ autor estudou duas propriedades localizadas na cidade de Toledo-PR, a primeira propriedade com a atividade da bovinocultura de leite e a segunda a suinocultura, enfatizando que em ambas utilizou-se o biofertilizante na agricultura. Foi avaliada a eficiência técnica e econômica para a geração de energia elétrica a partir do biogás e se constatou que, na segunda propriedade (produção de suínos), a geração de energia foi mais eficiente, consumindo valores menores de biogás. No entanto, Coldebella (2006, p. 52) frisa: "não é possível afirmar que o mesmo seja mais eficiente que o biogás da bovinocultura, pois as condições de operação e os equipamentos utilizados não apresentam as mesmas características". 
No estudo de caso acerca do aproveitamento dos dejetos suínos para a produção de biogás na granja Suinutri, Machado (2009) constatou que os biodigestores mostraram-se eficientes na redução de poluentes e na geração de biogás, transformando grandes quantidades de dejetos em energia, evitando assim as potenciais emissões de gases para a atmosfera e agregando valor para a indústria. No entanto, quanto ao uso do biofertilizante, os resultados do estudo não foram satisfatórios, demonstrando valores de nutrientes menores do que o parâmetro citado por Diesel (2002). Neste caso, de acordo com o autor, uma solução seria a redução do teor de água misturado ao dejeto, que pode ser obtido com a diminuição da quantidade de água utilizada no manejo da granja ou com uma mudança na estrutura da granja, a fim de evitar que água de chuva infiltre junto à biomassa. Caso não seja possível aumentar o teor de nutrientes do efluente, Machado (2009) argumenta a necessidade de se avaliar outro método de tratamento final para os dejetos.

De acordo com Ranzi e Andrade (2004), $1 \mathrm{~m}^{3}$ de biogás corresponde a $0,45 \mathrm{Kg}$ de gás GLP, portanto $30 \mathrm{~m}^{3}$ de biogás equivalem a aproximadamente um botijão de $13 \mathrm{Kg}$ de GLP. Partindo-se deste pressuposto e considerando que o custo médio de um botijão de $13 \mathrm{Kg}$ em 2004 era de aproximadamente $R \$ 30,00$, o autor estimou que o tempo de retorno do investimento na transformação de esterqueiras comuns em biodigestores rurais é de, aproximadamente, três meses. Desta forma, o autor constatou que as modificações necessárias nas propriedades para a produção do biogás obtêm um retorno relativamente curto se comparado com outros investimentos, mostrando uma alternativa viável economicamente.

Muitos estudos de caso sobre o assunto constatam que se torna inviável a instalação de biodigestores em propriedades com baixa produção de suínos devido à baixa quantidade produzida de dejetos, porém não são conhecidos estudos que demonstrem a partir de que nível de produção a geração de biogás se torna viável economicamente. 


\section{Elementos metodológicos}

Este trabalho constitui um estudo de caso, no entanto houve a necessidade de utilizar dados de fontes secundárias a fim de incrementálo. A unidade analisada foi as granjas do produtor Jan Haasjes, das quais se coletaram informações acerca do primeiro semestre de 2012 referentes à produção de suínos, custos de produção, receita, investimentos em biodiegestores, produção de biogás, entre outros. A propriedade está localizada na cidade de Castro, no Paraná. Numa das propriedades (Chácara Marujo), são desenvolvidas as atividades de suinocultura e agricultura, sendo o biogás utilizado como tratamento dos dejetos gerados nas granjas e fonte de economia de energia, além da utilização dos dejetos tratados como biofertilizante na agricultura. $O$ produtor possui outras duas chácaras, nas quais realiza parte da engorda do plantel, contudo os dejetos gerados nestas granjas são destinados à compostagem.

$\mathrm{Na}$ Chácara Marujo estão instalados dois biodigestores, destacando que o biodigestor principal foi construído no modelo Canadense, em síntese, uma cova de formato retangular, com sistema de agitação e aquecimento simples, composto por serpentinas de água aquecida que passam por canos PVC, revestidos e cobertos de manta PEAD, com capacidade de $1450 \mathrm{~m}^{3}$. O segundo biodigestor é utilizado como pós-fermentador e trata-se de um recipiente de alvenaria redondo, coberto com vinimanta de PVC, com capacidade de $1500 \mathrm{~m}^{3}$ de matéria orgânica. Utiliza-se para a geração e compressão do biogás um motor de $30 \mathrm{Kw}$, que normalmente trabalha 8 horas por dia. O mercado já foi pré-determinado pelo proprietário da Chácara na qual foi realizado este estudo, sendo o biogás utilizado para suprir parte da demanda por energia da mesma propriedade. Não existem fornecedores, pois são aproveitados os resíduos advindos da produção de suínos, atividade principal do proprietário. Portanto, trata-se de uma análise peculiar na qual se busca analisar se a energia/gás produzidos traz retornos econômicos que compensem o investimento feito em biodigestores. 
Deacordo com Buarque(1984), os objetivos do estudo da viabilidade econômica se resumem em avaliar quantitativamente as alternativas, tomando como base para decisão a economia que cada uma oferece. A fim de analisar a viabilidade da utilização de biodigestores como fonte de tratamento de dejetos da suinocultura e possível agregação de renda ao produtor, foram realizadas algumas etapas:

1) Análise do custo de produção, da receita e do lucro que o produtor teria sem estar utilizando biodigestores - ou seja, referindo aos resultados econômicos da suinocultura-, constituindo uma análise ex ante à implantação dos biodigestores. Ressalta-se que as informações sobre os custos referem-se ao primeiro semestre de 2012 (para uma venda mensal de 1900 leitões), em que a única informação colocada na planilha que não corresponde ao que se efetivou na propriedade foi quanto ao consumo de energia elétrica, valor este estimado pelo proprietário, com preço pago pela população rural (ou seja, tarifa subsidiada). Além de mensurar esses retornos econômicos da suinocultura do senhor Jan, estimou-os também para a média dos suinocultores paranaenses, pegando dados da Conab para o primeiro semestre de 2012, tendo em vista que a produção do senhor Jan apresenta algumas particularidades (como a produção de parte de seus insumos, salários maiores a seus trabalhadores, alto número de funcionários, custo com manutenção das casas dos funcionários, dentre outros) que o diferenciam da maioria dos produtores paranaenses. Desta forma, para que os resultados apresentados neste trabalho possam servir de referência para os demais produtores paranaenses, optou-se por calcular esses indicadores econômicos da suinocultura para os valores médios do Paraná.

2) Mensuração do uso de dejetos na propriedade e conversão dos mesmos em biogás. Essa foi denominada de "situação (a)". Na "situação (b)" foi identificado quanto de dejeto ao todo todas as granjas do senhor Jan estão produzindo (com o plantel atual de 880 matrizes e venda mensal de 1900 leitões) e quanto isso geraria de biogás. Na situação denominada "(c)" foi identificado qual o plantel necessário de suínos para que se utilizasse a capacidade máxima dos biodigestores instalados na propriedade (ao todo, a capacidade dos biodigestores instalados é de 
$2.950 \mathrm{~m}^{3}$ de dejetos por mês e estão sendo utilizados na "situação (a)" apenas $38,2 \%$ dessa capacidade).

3) Análise do investimento necessário para a implementação dos biodigestores, a preço de 2012, considerando a tecnologia e o modelo usado na propriedade descritos anteriormente.

4) Análise ex post à implantação dos biodigestores, quantificando agregação de renda e a viabilidade econômica que se teria ao estar transformando os dejetos suínos, por meio do cálculo da Taxa Interna de Retorno (TIR), Payback descontado e Valor Presente Líquido (VPL) 1 . Nesta análise, fizeram-se duas hipóteses, analisando as três situações: (a), na qual é o uso atual de dejetos na propriedade do senhor Jan; (b), utilização total dos dejetos produzidos nas propriedades do senhor Jan, e; (c), utilização total dos biodigestores. A Primeira Hipótese é a de que todo o biogás produzido nas três situações é transformado em energia elétrica, em que parte seria consumida internamente nas granjas (chamado de renda não monetária) e parte seria vendido. Nesta primeira hipótese, levaram-se em consideração primeiramente os dados de consumo e de preço pago pela energia elétrica dos suinocultores como um todo do Estado e, na sequência, consideraram-se os dados do senhor Jan (todos os valores definidos na etapa "um" do trabalho). Na Segunda Hipótese, mensurou-se a viabilidade econômica, considerando o uso do biogás que o senhor Jan faz atualmente na propriedade.

\section{Produção de biogás de dejetos suínos: estudo de caso}

Neste estudo, tratou-se do aproveitamento do potencial energético gerado pelo tratamento dos resíduos suínos em biodigestores e da possível agregação de renda que estes podem gerar para o suinocultor. Desta forma, o produto em questão é a energia, com a qual o produtor pode utilizar tanto o próprio biogás gerado e comprimido, como também pode utilizar motores geradores para transformá-lo em energia elétrica.

A Chácara Marujo, sede das granjas do Sr Jan Haasjes, está localizada na PR 340, Km 190 na cidade de Castro-PR, com uma área 
de 140 hectares. A propriedade possui 15 casas de funcionários, além da casa do proprietário, escritório, oficina, secador de grãos, 2 biodigestores e outras estruturas menores, necessárias para o desenvolvimento das atividades. A granja de suínos utiliza o sistema de ciclo fechado em sua produção, contando com duas propriedades filiais para a engorda.

O produtor conta com 22 funcionários trabalhando nas granjas de suínos, 2 no escritório e 1 funcionário que cuida dos biodigestores.

O sistema de produção do Sr. Jan abrigou no primeiro semestre de 2012, em média, 880 matrizes em seu plantel e, de acordo com o site Gazeta Digital (2010), pode ser considerada uma produção de grande porte comercial por possuir mais que 100 matrizes. A capacidade das granjas do Sr. Jan Haasjes é utilizada conforme a Tabela 1.

Tabela 1 - Quantidade de animais no plantel em 2012, por classificação - Mensal

\begin{tabular}{l|c|c|c|c|c|c}
\hline & JANEIRO & FEVEREIRO & MARÇO & ABRIL & MAIO & JUNHO \\
\hline CRIADEIRAS & 856 & 880 & 883 & 867 & 903 & 893 \\
CACHAÇOS & 6 & 5 & 5 & 5 & 6 & 6 \\
MARRÃS & 52 & 52 & 52 & 52 & 52 & 52 \\
CRECHE & 2800 & 2888 & 2912 & 2900 & 2800 & 2800 \\
ENGORDA & 7054 & 7286 & 7900 & 7826 & 7046 & 7046 \\
\hline
\end{tabular}

Fonte: Resultado da pesquisa, com informações coletadas diretamente na propriedade.

Na Tabela 1 foram mantidas as nomenclaturas e classificações conforme o controle interno da Chácara. Como a reprodução ocorre na propriedade, o número de animais e seu tempo de vida não são constantes, devido a diferenças naturais de número de crias, tempo de gestação, perdas, entre outros fatores. Destaca-se que na Chácara Marujo ficam apenas 35\% dos animais da engorda, ou seja, em torno de 2.575 animais, com peso que varia entre 25 e $100 \mathrm{~kg}$.

A quantidade de dejetos gerada varia de acordo com a fase produtiva do animal (Tabela 2). Cada suíno adulto em fase de engorda produz, em média, de 7 - 8 litros de dejetos líquidos ao dia ou 0,21 - 
$0,24 \mathrm{~m}^{3}$ de dejetos por mês. Nas demais fases, a quantidade de dejetos produzidos varia conforme mostra a Tabela 2.

Tabela 2 - Produção média diária de dejetos suínos por fase animal.

\begin{tabular}{l|c|c|c}
\hline Categoria & $\begin{array}{r}\text { Esterco } \\
\text { (Kg/dia) }\end{array}$ & $\begin{array}{r}\text { Esterco + } \\
\text { Urina (Kg/dia) }\end{array}$ & $\begin{array}{c}\text { Dejetos Líquidos } \\
\text { (Litros/dia) }\end{array}$ \\
\hline Porca Gestação & 3,6 & 11,0 & 16,0 \\
Cachaços & 3,0 & 6,0 & 9,0 \\
Porca lactação + Leitões & 6,4 & 18,0 & 27,0 \\
Leitões na creche & 0,4 & 1,0 & 1,4 \\
Suínos (25-100 Kg) & 2,3 & 4,9 & 7,0 \\
\hline
\end{tabular}

Fonte: Diesel (2002).

Na propriedade estudada, o biodigestor é alimentado diariamente com o valor estimado de aproximadamente 37.560 litros de dejetos suínos por dia, equivalendo 1.126 .800 litros por mês, cálculo realizado com base nos valores fornecidos por Diesel (2002) - Tabela 2 - e dados do plantel existente na Chácara Marujo em 2012 - Tabela 1, descontando $65 \%$ da engorda que pertence às outras propriedades. Assim, só os dejetos da Marujo são transformados no biodigestor.

Os dejetos de suínos são encaminhados automaticamente através de tubulações para uma fossa, na qual são agitados para homogeneizar e, posteriormente, são encaminhados para o fermentador principal, local onde permanecem por aproximadamente 30 dias. Quando a capacidade do biodigestor principal é excedida, o efluente é encaminhado automaticamente para o pós-fermentado, passando mais uma vez pela biodigestão e, após, o efluente restante é encaminhado para a lavoura conforme a necessidade. A fossa e os biodigestores estão localizados cerca de 200 metros das granjas, em uma parte de desnível do terreno, podendo o produtor assim contar com a gravidade para encaminhar os dejetos. 


\subsection{Analise ex ante: renda gerada pela suinocultura}

Com o objetivo de identificar, ex post, qual seria a elevação de renda dos suinocultores, se estes transformassem os dejetos de suínos nos biodigestores, é que se construiu essa seção, ou seja, é identificado o lucro dos suinocultores para, em seguida, ver o quanto este aumenta se utilizar os biodigestores no processo. Como o produtor analisado tem algumas características que o diferem da grande maioria dos suinocultores paranaenses (como produzir parte da sua ração, fazer a reprodução na Marujo dos leitões para suprir a reposição da engorda de mais duas propriedades, além de se ter gastos mensais com a casa dos funcionários), então optou-se por considerar na análise de incremento na renda o custo médio de produção de suínos do Paraná, custo este necessário para produzir o plantel de 1.900 suínos terminados por mês (quantidade vendida mensalmente pelo Sr. Jan Haasjes). Depois de efetuadas as análises e hipóteses com o custo de produção estimado para o Paraná, são apresentadas as informações individuais do produtor.

- Produção do Paraná: plantel 1.900 suínos terminados vendidos ao mês

Analisando, então, o custo de produção de suínos no Paraná para um plantel semelhante ao da propriedade analisada (considerando o ciclo completo, ou seja, desde a produção dos filhotes até a engorda, com produção mensal de 1900 suínos terminados, com $100 \mathrm{~kg}$ cada), tem-se a Tabela 4.3, com dados referentes ao primeiro semestre de 2012, valores calculados a partir dos custos de produção de Suínos disponíveis no acervo histórico da CONAB (2012).

De acordo com o Sindicarne (2012), o preço médio do quilo da carne suína no primeiro semestre de 2012 ficou cotado em $R$ \$2,45. Conforme já citado, a propriedade estudada comercializa mensalmente 1.900 suínos terminados com $100 \mathrm{Kg}$ de peso vivo cada (quantidade estimada também para produção paranaense), desta forma, a receita média mensal seria igual a $R \$ 465.500,00$. 
Ao deduzir o custo total da receita obtida, o lucro mensal encontrado é apresentado na Tabela 3. Anualmente, a receita auferida seria de $\mathrm{R} \$$ $5.586 .000,00$ com um custo total equivalente à $R \$ 5.419 .135,84$, obtendo um lucro anual igual a $\mathrm{R} \$ 166.864,16$.

Tabela 3 - Indicadores econômicos estimados da produção de suínos no Paraná - Venda de 1.900 suínos ao mês - ciclo completo - 2012

\begin{tabular}{l|c|c|c|c}
\hline Período & Receita & Custos & R. Líquida & Margem de Lucro \% \\
\hline Janeiro & $465.500,00$ & $443.714,31$ & $21.785,69$ & 4,680062 \\
Fevereiro & $465.500,00$ & $447.444,10$ & $18.055,90$ & 3,878819 \\
Março & $465.500,00$ & $452.074,42$ & $13.425,58$ & 2,884121 \\
Abril & $465.500,00$ & $443.568,35$ & $21.931,65$ & 4,711417 \\
Maio & $465.500,00$ & $452.898,17$ & $12.601,83$ & 2,707161 \\
Junho & $465.500,00$ & $469.868,57$ & $-4.368,57$ & $-0,938468$ \\
Média & $465.500,00$ & $451.594,65$ & $13.905,35$ & 2,987185 \\
\hline
\end{tabular}

Fonte: Resultado da pesquisa.

- Produção Sr Jan Haasjes: plantel 1.900 suínos terminados vendidos ao mês

A Tabela 4 mostra os custos, receitas e lucros referentes à produção do Sr. Jan, no primeiro semestre de 2012. Nota-se que, no geral, o produtor obteve uma média de lucro maior em 2012 que o indicador paranaense divulgado pela Conab. Essa diferença de 6,31\% a mais na margem percentual de lucro se dá principalmente pelo custo da alimentação que nas granjas estudadas representa $18,22 \%$ a menos que na estimativa paranaense - se comparado à média do semestre - principalmente, pelo produtor produzir parte da alimentação que é fornecida para o plantel. Por ano, o produtor obtém um lucro estimado igual a $\mathrm{R} \$ 519.267,78$, considerando a receita média de $\mathrm{R} \$ 5.586 .000,00$ e o custo de $\mathrm{R} \$ 5.066 .732,22$. 
Tabela 4 - Indicadores econômicos estimados da produção de suínos do Sr. Jan Haasjes - Venda de 1.900 suínos ao mês - 2012

\begin{tabular}{l|c|c|c|c}
\hline Período & Receita & Custos & R. Líquida & Margem de Lucro \% \\
\hline Janeiro & $465.500,00$ & $351.422,02$ & $114.077,98$ & 24,506548 \\
Fevereiro & $465.500,00$ & $376.712,53$ & $88.787,47$ & 19,073571 \\
Março & $465.500,00$ & $378.124,40$ & $87.375,60$ & 18,770269 \\
Abril & $465.500,00$ & $494.838,90$ & $-29.338,90$ & $-6,302664$ \\
Maio & $465.500,00$ & $496.512,72$ & $-31.012,72$ & $-6,662238$ \\
Junho & $465.500,00$ & $435.755,55$ & $29.744,45$ & 6,389786 \\
Média & $465.500,00$ & $422.227,68$ & $43.272,32$ & 9,295879 \\
\hline
\end{tabular}

Fonte: Resultado da pesquisa.

\subsection{Investimentos necessários para a produção de biogás}

$\mathrm{Na}$ Chácara Marujo, estão instalados dois biodigestores. $\mathrm{O}$ biodigestor principal é do modelo canadense, revestido e coberto com manta PEAD (polietileno de alta densidade), com capacidade de armazenamento de $1.450 \mathrm{~m}^{3}$ de matéria orgânica. O segundo biodigestor, chamado de pós-fermentador, é um recipiente redondo de alvenaria, coberto com manta PEAD, com capacidade de $1.500 \mathrm{~m}^{3} \mathrm{de}$ matéria orgânica, sem modelo específico.

Os dejetos passam por uma tubulação saindo direto das pocilgas para um reservatório, no qual são agitados antes de entrarem no biodigestor. No biodigestor principal, a matéria orgânica incide por um processo de digestão anaeróbica, que resulta na liberação do biogás, o qual é bombeado e comprimido por dois horímetros. O gás é encaminhado aos pontos de utilização distribuídos na Chácara, por meio de tubulações de cano PVC que, ao todo, somam mais de 1.400 metros de condutores. O biogás é utilizado na Chácara em diversas finalidades: na granja, é realizado o aquecimento do piso das pocilgas em um sistema em que a água é aquecida e mantida em $40^{\circ} \mathrm{C}$ circulando por serpentinas abaixo do piso; o mesmo sistema é utilizado para o aquecimento do piso do escritório; é utilizado em substituição a 15 botijões de $13 \mathrm{Kg}$ de 
GLP ao mês (gás liquefeito de petróleo), distribuído entre as casas dos funcionários e em 4 chuveiros de aquecimento a gás; utilizado também em época de safra, na secagem de grãos. Quando sobra biogás, o excedente é encaminhado a um motor gerador de energia elétrica, chamado de "economizador de energia", por estar diretamente ligado ao sistema de fornecimento de energia elétrica.

A tecnologia do biodigestor é simples, porque, na realidade, o processo de produção de gás ocorre naturalmente na matéria orgânica, contudo o biodigestor cria um ambiente propicio às bactérias, proporcionando assim aceleração no processo, eficiência na geração e meios de captação do gás. No caso do material orgânico de origem animal, como do dejeto suíno, já existem bactéria metanogênicas em número suficiente, o que não ocorre com outros tipos de resíduos nos quais se faz necessária a inoculação de esterco animal para acelerar o processo.

A Tabela 5 mostra o custo a preços de 2012, que o produtor teve com a construção do biodigestor e também o custo com as modificações e adaptações na estrutura da chácara necessárias para o aproveitamento do biogás.

Tabela 5 - Custos do biodigestor e adaptações - 2012.

\begin{tabular}{lrr}
\hline CUSTOS & \multicolumn{2}{c}{ VALOR (R\$) } \\
\hline Caixa de preparo com agitador de inox & $\mathrm{R} \$$ & $21.000,00$ \\
Biodigestor principal & $\mathrm{R} \$$ & $43.400,00$ \\
Pós-fermentador & $\mathrm{R} \$$ & $40.000,00$ \\
Gerador de energia elétrica & $\mathrm{R} \$$ & $40.000,00$ \\
Redes e chaves elétricas & $\mathrm{R} \$$ & $18.600,00$ \\
Compressores de gás e tubulações & $\mathrm{R} \$$ & $37.200,00$ \\
Caldeira nas pocilgas & $\mathrm{R} \$$ & $49.600,00$ \\
Tubulações e serpentinas de água quente & $\mathrm{R} \$$ & $37.200,00$ \\
Queimadores e adaptações & $\mathrm{R} \$$ & $12.400,00$ \\
Mão de obra: instalação, montagem, etc. & $\mathrm{R} \$$ & $110.000,00$ \\
Taxas e licenciamentos & $\mathrm{R} \$$ & $3.000,00$ \\
Total investimento & $\mathrm{R} \$$ & $412.400,00$ \\
\hline
\end{tabular}

Fonte: Resultado da pesquisa, com Informações coletadas diretamente na propriedade. 


\subsection{Produção de biogás e viabilidade}

Conforme explica Ribeiro et al. (2012), para estimar a produção de biogás, é necessário conhecer o grau de diluição dos dejetos, encontrando os Sólidos Totais ou a Matéria Seca presente nos dejetos, que de acordo com Oliveira e Igarashi (2006 apud Ribeiro et al., 2012) representa um teor médio de $3 \%$ em função do desperdício de água existente nas propriedades. Destes 3\% de Sólidos Totais (ST), para o caso dos suínos, entre 70 a $75 \%$ representam os Sólidos Voláteis (SV), que são os substratos para as bactérias metanogênicas. Para o caso dos dejetos suínos, a produção de biogás é de $0,45 \mathrm{~m}^{3} / \mathrm{kg}$ de SV.

A quantidade de dejetos estimada, de acordo Diesel (2002), para o plantel da Chácara Marujo está representada na Tabela 4.6, em que foi utilizada a quantidade média de animais abrigados na Chácara de janeiro a junho de 2012 e os valores de produção de dejetos estimados por Diesel (2002) - Tabelas 1 e 2. Lembrando que os biodigestores estão instalados na Chácara Marujo e nesta ficam apenas 35\% dos suínos em fase de engorda e os demais são divididos entre as outras duas propriedades; assim, para a estimação da quantidade de dejetos produzidos e transformados, foi utilizada essa proporção. Ao todo, são gerados em torno de 2.131.440 litros de dejetos ao mês (Tabela 6), dos quais somente $52,87 \%$ são conduzidos aos biodigestores, os demais $47,13 \%$ são utilizados na compostagem.

$\mathrm{Na}$ análise na qual considera apenas a produção de 1.126.800 litros de dejetos por mês, a produção mensal de biogás estimada ${ }^{2}$ é igual a: $1.126 .800 \times 0,03 \times 0,75 \times 0,45=11.408,85 \mathbf{m}^{3}$. É importante ressaltar que a capacidade total de armazenamento de dejetos nos biodigestores é de $2.950 \mathrm{~m}^{3}$, e que a quantidade utilizada com dejetos da suinocultura, atualmente, é de $1.126,80 \mathrm{~m}^{3}$, ou seja, utiliza-se apenas $38,2 \%$ da capacidade do biodigestor, restando $61,8 \%$ de capacidade ociosa. Ao ano, com esse uso do biodigestor, a produção de biogás seria igual a $136.906,20 \mathrm{~m}^{3}$. 
Tabela 6 - Quantidade média ao mês de dejetos produzidos por parte do plantel de suínos (somente da Marujo) no primeiro semestre de 2012.

\begin{tabular}{lccccc}
\hline Animais & Qtd Média & Dejetos $\mathbf{~ m}^{3} /$ dia & Dejetos L/dia & Dejetos L/mês \\
\hline Criadeiras & 880 & 14,08 & 14.080 & 422.400 \\
Cachaços & 6 & 0,05 & 54 & 1.620 \\
Marrãs & 52 & 1,40 & 1.404 & 42.120 \\
Creche & 2.850 & 3,99 & 3.990 & 119.700 \\
Engorda & 2.576 & 18,03 & 18.032 & 540.960 \\
Total & & $\mathbf{3 7 , 5 6}$ & $\mathbf{3 7 . 5 6 0}$ & $\mathbf{1 . 1 2 6 . 8 0 0}$ \\
\hline
\end{tabular}

Fonte: Resultado da pesquisa.

Se todo o dejeto produzido nas granjas do Senhor Jan fossem transformados nos biodigestores (Tabela 7), ter-se-ia uma produção de biogás igual a: 2.131.440 x 0,03 x 0,75 x 0,45 = 21.580,83 $\mathrm{m}^{\mathbf{3}}$ ao mês, com uma produção anual de 258.969,96 $\mathrm{m}^{3} \mathrm{e}$, mesmo assim, ter-se-ia uma ociosidade dos biodigestores.

Tabela 7 - Quantidade média ao mês, de dejetos produzidos por todo o plantel de suínos no primeiro semestre de 2012.

\begin{tabular}{lccccc}
\hline Animais & Qtd Média & Dejetos $\mathbf{m}^{\mathbf{3}}$ dia & Dejetos L/dia & Dejetos L/mês \\
\hline Criadeiras & 880 & 14,08 & 14.080 & 422.400 \\
Cachaços & 6 & 0,05 & 54 & 1.620 \\
Marrãs & 52 & 1,40 & 1.404 & 42.120 \\
Creche & 2.850 & 3,99 & 3.990 & 119.700 \\
Engorda & 7.360 & 51,52 & 51.520 & 1.545 .600 \\
Total & & 71,05 & 71.048 & 2.131 .440 \\
\hline
\end{tabular}

Fonte: Resultado da pesquisa. 
Ao passo que, se toda a capacidade do biodigestor viesse a ser utilizada, ter-se-ia uma produção mensal de biogás igual a: 2.950.000 $\times 0,03 \times 0,75 \times 0,45=\mathbf{2 9 . 8 6 8 , 7 5 m ^ { 3 }}$. Para isso, seriam necessários 2.950 .000 litros de dejetos, com uma estimativa de plantel igual a 1.218 matrizes e 2.630 suínos terminados entregues ao mercado ao mês. Anualmente, a produção de biogás nesta situação seria igual a 358.425 $\mathrm{m}^{3}$.

Assim, a Tabela 8 retrata bem como estão sendo utilizados os biodigestores hoje em dia e como estariam sendo utilizados, considerando toda a transformação de dejetos produzidos nas granjas do Sr. Jan e a hipótese dos biodigestores estarem trabalhando com 100\% de capacidade utilizada, destacando que todos os dados são anuais.

Tabela 8 - Biodigestores, sua capacidade ociosa e plantel necessário ao ano.

\begin{tabular}{l|c|c|c}
\hline Situações (Plantel): & $\begin{array}{c}\text { Dejetos produzidos } \\
\text { ao ano (L) }\end{array}$ & $\begin{array}{c}\text { Biogás ao } \\
\text { ano (m3) }\end{array}$ & $\begin{array}{c}\text { Capacidade } \\
\text { Ociosa }\end{array}$ \\
\hline $\begin{array}{l}\text { Marujo: } 850 \text { matrizes; } 665 \\
\text { terminados (a) }\end{array}$ & $13.521 .600,00$ & $136.906,20$ & $61,80 \%$ \\
$\begin{array}{l}\text { Granjas Jan: } 850 \text { matrizes; } \\
\text { 1900 terminados (b) }\end{array}$ & $25.577 .280,00$ & $258.969,96$ & $27,75 \%$ \\
$\begin{array}{l}\text { Hipótese: } 1.218 \text { matrizes; } \\
2.630 \text { terminados(c) }\end{array}$ & $35.400 .000,00$ & $358.425,00$ & $0 \%$ \\
\hline
\end{tabular}

Fonte: Resultado da pesquisa.

As três situações descritas na Tabela 8 - em que a situação (a) é a atual, na (b) é a possível de se alcançar com o plantel existente do produtor analisado e na (c) é a utópica, cabível desde que se aumente o plantel, usando toda a capacidade do biodigestor - demonstram o quanto se pode alterar a produção de biogás, desde que se modifique a forma como vem se usando o biodigestor. Essas três situações serão analisadas na sequência, em cada um dos cenários construídos para a propriedade. 


\subsubsection{Primeira Hipótese: todo biogás gerado é convertido em energia elétrica a qual atende ao consumo interno da propriedade e o excedente é vendido}

De acordo com as referências encontradas na literatura - BLEY JR et al. (2009 apud Ribeiro et al. 2012), BARRICHELLO 2011 - argumentam que a conversão do biogás com $65 \%$ de metano em energia elétrica varia de 1,43-1,8 kWh por $\mathrm{m}^{3}$ de biogás, para grupos de motogeradores com motores de Ciclo Otto.

Utilizando a produção de biogás estimada para a produção de dejetos da Chácara Marujo (situação "a" da Tabela 8), tem-se que a geração de energia variaria de $16.314,66$ kWh a 20.535,93 kWh ao mês, com valor médio de 18.425,30 kWh (ou 18,42 MWh), destacando que está se utilizando apenas $38,2 \%$ da capacidade do biodigestor. Anualmente, estaria se produzindo com esta capacidade utilizada o equivalente a 221,10 MWh.

Na situação (b), se todo biogás fosse convertido em energia considerando que todos os dejetos produzidos nas granjas do Sr. Jan estariam indo para os biodigestores -, teria uma produção de energia média igual a 419,53 MWh por ano.

Por fim, na última situação (c) - ou seja, usando a capacidade máxima dos biodigestores - o total de energia elétrica produzido seria de 580,65 MWh ao ano.

- Primeiro cenário - trabalhado com o custo estimado para o Paraná Receitas:

Informações obtidas junto à distribuidora Copel discorrem que o valor pago pelo $\mathrm{MWh}$ de energia elétrica para os produtores rurais situa-se em torno de $90 \%$ do valor de referência, que é $\mathrm{R} \$ 135,38$, ficando em R\$121,84 por MWh e o valor de mercado da energia elétrica pagos pelos produtores em torno de $\mathrm{R} \$ 283,12$. Considerando os dados da Conab (2012) acercado custo de produção dos suínos, o consumo médio estimado de energia elétrica no Paraná para o plantel 1.900 suínos terminados é de 8.069,41 kWh ao mês. 
Assim, na situação (a), em que apenas 38,2\% da capacidade do biodigestor estão sendo utilizadas, a geração de energia elétrica é de 18.425,30 kWh, resultando em uma sobra de 10.355,89 kWh que, vendidos ao preço pago pela Copel ( $R$ \$ 0,12184/kWh), gerariam uma renda monetária de $R \$ 1.261,76$ mensais. A redução de custo para o suinocultor (consumo interno), chamada de renda não monetária, seria igual à $\mathrm{R} \$ 2.284,61$.

$\mathrm{Na}$ situação (b), que tem como pressuposto que todo o dejeto gerado pelo plantel de suínos é encaminhado para o biodigestor resultando na utilização de $72,25 \%$ da capacidade instalada, seria gerado o equivalente a $34.960,94 \mathrm{kWh}$. Com o consumo médio de $8.069,41 \mathrm{kWh}$, ter-se-ia $26.891,53 \mathrm{kWh}$ ao mês vendidos, gerando R\$ $3.276,46$ de renda adicional.

Na situação (c), em que $100 \%$ da capacidade do biodigestor seria utilizada, a propriedade geraria 48.387,38 kWh, consumindo mensalmente o equivalente a $11.169,75 \mathrm{kWh}$ para o plantel estimado 3 . Assim, teria $37.217,63 \mathrm{kWh}$ de excedente de energia elétrica, possibilitando a geração de uma renda adicional de $\mathrm{R} \$ 4.534,60$ ao mês.

$\mathrm{Na}$ tabela 9, as receitas monetárias e não monetárias estão sintetizadas ao ano, para cada situação analisada.

Tabela 9 - Receitas monetárias e não monetárias geradas com a conversão de todo o biogás em energia elétrica - Custos Paraná valores a preço de 2012

\begin{tabular}{|c|c|c|c|c|}
\hline \multirow[t]{2}{*}{ Situações (Plantel) } & \multicolumn{3}{|c|}{$\begin{array}{c}\text { Receita anual com a energia } \\
\text { elétrica }\end{array}$} & \multirow{2}{*}{$\begin{array}{l}\text { Receita anual } \\
\text { total }\end{array}$} \\
\hline & & onsumo & Venda & \\
\hline $\begin{array}{l}\text { Marujo: } 850 \text { matrizes; } 665 \\
\text { terminados } \quad \text { (a) }\end{array}$ & $\mathrm{R} \$$ & $27.415,32$ & $\mathrm{R} \$ 15.141,12$ & $\mathrm{R} \$ 42.556,44$ \\
\hline $\begin{array}{l}\text { Granjas Jan: } 850 \text { matrizes; } \\
1900 \text { terminados (b) }\end{array}$ & $\mathrm{R} \$$ & $27.415,32$ & $\mathrm{R} \$ 39.317,52$ & $\mathrm{R} \$ 66.732,84$ \\
\hline $\begin{array}{l}\text { Hipótese: } 1.218 \text { matrizes; } \\
2.630 \text { terminados(c) }\end{array}$ & $\mathrm{R} \$$ & $37.948,56$ & $\mathrm{R} \$ 54.415,20$ & $\mathrm{R} \$ 92.363,76$ \\
\hline
\end{tabular}

Fonte: Resultado da pesquisa. 


\section{Investimento}

Com base na hipótese trabalhada, de que todo o biogás seria utilizado para a geração de energia elétrica, ter-se-ia o investimento inicial de $\mathrm{R} \$ 225.886,44$ descrito na Tabela 10. A diferença entre este investimento e o apresentado na Tabela 5 é que muitos dos equipamentos usados atualmente na propriedade (a qual gera energia elétrica e utiliza o biogás para vários fins) não seriam necessários quando está se fazendo a suposição apenas de produção de energia elétrica com o biogás gerado - hipótese 1 .

Tabela 10 - Investimentos necessários para o tratamento dos dejetos nos biodigestores, considerando a transformação do biogás em energia elétrica - valores a preço de 2012.

\begin{tabular}{lrr}
\hline CUSTOS & \multicolumn{2}{c}{ VALOR (R\$) } \\
\hline Caixa de preparo com agitador de inox & $\mathrm{R} \$$ & $21.000,00$ \\
Biodigestor principal & $\mathrm{R} \$$ & $43.400,00$ \\
Pós-fermentador & $\mathrm{R} \$$ & $40.000,00$ \\
Gerador de energia elétrica & $\mathrm{R} \$$ & $40.000,00$ \\
Redes e chaves elétricas & $\mathrm{R} \$$ & $18.600,00$ \\
Mão de obra: instalação, montagem etc. & $\mathrm{R} \$$ & $59.886,44$ \\
Taxas e licenciamentos & $\mathrm{R} \$$ & $3.000,00$ \\
Total investimento & $\mathrm{R} \$$ & $225.886,44$ \\
\hline
\end{tabular}

Fonte: Resultado da pesquisa.

\section{Fluxo de caixa}

De forma geral, fluxo de caixa é o montante de receitas e despesas de um empreendimento em um determinado período de tempo. Neste trabalho, optou-se por trabalhar com preços constantes, com valores coletados e estimados a preços do primeiro semestre de 2012 .

As receitas anuais já calculadas anteriormente estão na Tabela 4.9. O custo médio de manutenção mensal é $\mathrm{R} \$ 518,87$, o qual corresponde aos gastos com o salário e encargos do funcionário responsável pelo biodigestor $(418,87)^{4}$, mais o custo adicional de $R \$ 100,00$ com eventuais 
reparos. Ao todo, a despesa de manutenção corresponde anualmente ao montante de $\mathrm{R} \$ 6.226,44^{5}$. A Tabela 11 traz o fluxo de caixa anual para as situações trabalhadas.

Tabela 11 - Fluxo de caixa anual baseado nos custos estimados para o Paraná - a preço de 2012.

\begin{tabular}{|c|c|c|c|}
\hline Situações (Plantel) & Receitas & Despesas & Fluxo de Caixa \\
\hline $\begin{array}{l}\text { Marujo: } 850 \text { matrizes; } 665 \\
\text { terminados (a) }\end{array}$ & $\mathrm{R} \$ 42.556,44$ & $-R \$ 6.226,44$ & $\mathrm{R} \$ 36.330,00$ \\
\hline $\begin{array}{l}\text { Granjas Jan: } 850 \text { matrizes; } \\
1900 \text { terminados(b) }\end{array}$ & $\mathrm{R} \$ 66.732,84$ & $-\mathrm{R} \$ 6.226,44$ & $\mathrm{R} \$ 60.506,40$ \\
\hline $\begin{array}{l}\text { Hipótese: } 1.218 \text { matrizes; } \\
2.630 \text { terminados (c) }\end{array}$ & $\mathrm{R} \$ 92.363,76$ & $-\mathrm{R} \$ 6.226,44$ & $\mathrm{R} \$ 86.137,32$ \\
\hline
\end{tabular}

Fonte: Resultado da pesquisa.

Viabilidade do investimento

É importante determinar a vida útil do projeto em análise e a taxa mínima de atratividade para o mesmo. Para tanto, foi determinada a vida útil do biodigestor de 10 anos e para taxa mínima de atratividade foi utilizada a taxa Selic, que é a taxa referencial do Sistema de Liquidação e Custódia brasileiro, retirada do boletim Focus do Banco Central, publicado em 20 de abril de 2012, que esteve cotada em 9,1\% ao ano.

Foi utilizado o método do Payback descontado para obter o tempo de recuperação do capital investido, em que se verificou, conforme demonstrado na Tabela 12, que a melhor situação é a (c), pois nesta o capital será recuperado em menos de 4 anos. Destacando que na situação (a) o capital será recuperado apenas no último ano de vida do projeto.

Ao analisar o Valor Presente Líquido e a Taxa Interna de Retorno para cada situação, nota-se que estes dois métodos de análise confirmam a viabilidade constatada no Payback, apresentando para a situação (c) um VPL de R $\$ 324.488,48$ e uma Taxa Interna de Retorno de 36,43\%, 
valores superiores às demais situações analisadas. No entanto, ressaltase que mesmo para as outras duas situações ( $a$ e b), nas quais o uso do biodigestor está bem aquém da capacidade instalada, apresenta-se viável economicamente tal investimento.

Tabela 12 - Análise de viabilidade para a primeira hipótese considerando os custos do Paraná.

\begin{tabular}{l|c|c|c}
\hline Situação (plantel) & $\begin{array}{c}\text { Payback } \\
\text { (anos) }\end{array}$ & VPL & TIR \\
\hline $\begin{array}{l}\text { Marujo: 850 matrizes; } 665 \\
\text { terminados (a) }\end{array}$ & 9,589 & $\mathrm{R} \$ \quad 6.244,31$ & $9,73 \%$ \\
$\begin{array}{l}\text { Granjas Jan: } 850 \text { matrizes; } 1900 \\
\text { terminados(b) }\end{array}$ & 4,774 & $\mathrm{R} \$ 160.719,56$ & $23,56 \%$ \\
$\begin{array}{l}\text { Hipótese: } 1.218 \text { matrizes; } 2.630 \\
\text { terminados (c) }\end{array}$ & 3,135 & $\mathrm{R} \$ 324.488,48$ & $36,43 \%$ \\
\hline
\end{tabular}

Fonte: Resultado da pesquisa.

- Segundo cenário - trabalhado com o custo do produtor Receitas:

O produtor estudado é cooperado da Eletrorural, uma cooperativa de eletrificação rural em que grande parte dos produtores rurais locais são cooperados. Desta forma, o custo da energia elétrica cobrada a estes cooperados é de $\mathrm{R} \$ 195,37$ por MWh ou $\mathrm{R} \$ 0,19537$ por kWh.

Ao trabalhar com os custos de produção da Chácara Marujo, tem-se que o consumo mensal de energia elétrica é de 29,48 MWh ou 29.482,52 kWh ao mês (informações coletadas na propriedade), demandando ao ano o total estimado de 353.790,24 kWh.

Dada a situação (a) - em que o produtor destina apenas parte dos dejetos gerados nas suas granjas para o biodigestor, utilizando, desta forma, apenas $38,2 \%$ da capacidade do mesmo -, a geração de energia elétrica seria igual a $18.425,30 \mathrm{kWh}$, destacando que o produtor ainda teria que comprar da Eletrorural 11.057,22 kWh por mês. 
Assim, nota-se que, se o produtor utilizasse todo o biogás gerado para a produção de energia elétrica, ele consumiria os $18.425,30$ kWh produzidos no mês e ainda demandaria da Eletrorural 11.057,22 kWh. Neste caso, o produtor economizaria mensalmente R $\$ 3.599,75$, deixando de comprar parte da energia demandada pelas granjas.

Analisando a situação (b), em que todos os dejetos gerados pelo plantel estudado são destinados ao biodigestor, utilizando assim 72,25\% da capacidade deste, tem-se que a produção de biogás é de 21.580,83 $\mathrm{m}^{3}$ ao mês. Sendo gerado o equivalente a 34.960,94 kWh e sabendo que o consumo do produtor é de 29.482,52 kWh, haveria um excedente de $5.478,42 \mathrm{kWh}$ ao mês que, se vendido à Copel (preço pago $\mathrm{R} \$ 0,12184$ / $\mathrm{kWh})$, geraria a receita mensal de $\mathrm{R} \$ 667,49$.

Na situação (c), em que a utilização da capacidade do biodigestor é maximizada, a produção de biogás passaria para 29.868,75 $\mathrm{m}^{3}$ mensais, gerando em média 48.387,38 kWh. Como o plantel analisado na situação (c) é maior que o atual (situação "a" e "b"), então a demanda de energia para produzir esse número de leitões também seria maior, com uma estimativa de consumo de 40.810,01 kWh ao mês. Neste caso, ter-se-ia um excedente de 7.577,37 kWh por mês, que poderiam gerar uma receita de $\mathrm{R} \$ 923,23$, se vendidos à Copel.

Desta forma, a receita anual auferida com a venda de energia elétrica excedente mais a receita não monetária - referindo-se ao custo que o produtor deixou de ter por estar produzindo ele mesmo a sua energia - seria igual a $R \$ 43.197, R \$ 77.130, R \$ 106.755$, considerando as situações (a), (b) e (c), respectivamente (Tabela 13). Destaca-se que na situação (a) não haveria excedente a ser vendido, na situação (b) seria vendido o montante de 65,7408 Mwh, e na (c) seria o equivalente a 226,8583 Mwh por ano. 
Tabela 13 - Receitas monetárias e não monetárias geradas com a conversão de todo o biogás produzido, em energia elétrica - Custos Jan - valores a preço de 2012

\begin{tabular}{|c|c|c|c|c|}
\hline \multirow[t]{2}{*}{ Situações (Plantel) } & \multicolumn{3}{|c|}{ Receita anual c/ a energia elétrica } & \multirow{2}{*}{$\begin{array}{c}\text { Receita anual } \\
\text { Total }\end{array}$} \\
\hline & & nsumo & Venda & \\
\hline $\begin{array}{l}\text { Marujo: } 850 \text { matrizes; } 665 \\
\text { terminados }(a)\end{array}$ & $\mathrm{R} \$$ & $43.197,01$ & - & $\mathrm{R} \$ 43.197,01$ \\
\hline $\begin{array}{l}\text { Granjas Jan: } 850 \text { matrizes; } \\
1900 \text { terminados }(b)\end{array}$ & $\mathrm{R} \$$ & $69.120,00$ & $\mathrm{R} \$ 8.009,89$ & $\mathrm{R} \$ 77.129,89$ \\
\hline $\begin{array}{l}\text { Hipótese: } 1.218 \text { matrizes; } \\
2.630 \text { terminados (c) }\end{array}$ & $\mathrm{R} \$$ & $95.676,62$ & $\mathrm{R} \$ 11.078,72$ & $R \$ 106.755,34$ \\
\hline
\end{tabular}

Fonte: Resultado da pesquisa.

\section{Investimento}

Com base na Tabela 10, tem-se um investimento inicial de $\mathrm{R} \$$ $225.886,44$, necessário para construção dos biodigestores, montagens e adaptações necessárias para a geração de energia elétrica.

Fluxo de caixa

O custo de manutenção mensal dos biodigestores é $\mathrm{R} \$ 885,56$, sendo $\mathrm{R} \$ 785,56^{6}$ o custo da mão de obra demandada mensalmente e $\mathrm{R} \$ 100,00$ o valor estimado com despesas adicionais de manutenção. Resultando no montante de $\mathrm{R} \$ 10.626,68^{7}$ anuais com despesas de manutenção.

Na Tabela 14 está o fluxo de caixa anual para as diferentes situações (a), (b) e (c), a preços constantes.

Tabela 14 - Fluxo de caixa anual baseado nos custos das granjas do Sr. Jan Haasjes.

\begin{tabular}{|c|c|c|c|c|}
\hline Situações (Plantel) & & ceitas & Despesas & $\begin{array}{c}\text { Fluxo de } \\
\text { Caixa }\end{array}$ \\
\hline $\begin{array}{l}\text { Marujo: } 850 \text { matrizes; } 665 \\
\text { terminados (a) }\end{array}$ & $\mathrm{R} \$$ & $43.197,01$ & $-R \$ 10.626,68$ & $\mathrm{R} \$ 32.570,33$ \\
\hline $\begin{array}{l}\text { Granjas Jan: } 850 \text { matrizes; } 1900 \\
\text { terminados (b) }\end{array}$ & $\mathrm{R} \$$ & $77.129,89$ & $-R \$ 10.626,68$ & $R \$ 66.503,21$ \\
\hline $\begin{array}{l}\text { Hipótese: } 1.218 \text { matrizes; } 2.630 \\
\text { terminados (c) }\end{array}$ & \multicolumn{2}{|c|}{$\mathrm{R} \$ 106.755,34$} & $-\mathrm{R} \$ 10.626,68$ & $\mathrm{R} \$ 96.128,66$ \\
\hline
\end{tabular}

Fonte: Resultado da pesquisa. 


\section{Viabilidade do investimento}

Ao analisar a situação (a), nota-se que não apresenta viabilidade em nenhum dos métodos utilizados (4.15). Não há Payback, ou seja, durante o tempo de vida útil do projeto, o capital investido não será recuperado totalmente. O VPL resultou em valor negativo, o que indica que o retorno está abaixo do esperado, lembrando que a taxa de retorno esperada para as situações analisadas é expressa pela taxa SELIC do primeiro semestre de 2012 (9,1\%). A Taxa Interna de Retorno para esta situação é $7,27 \%$, ou seja, nesta situação o suinocultor teria um retorno menor que a taxa mínima de atratividade.

A situação (b) apresentou viabilidade, no entanto se comparada à situação (c), esta última traz um tempo de retorno do capital menor, em que o capital investido será totalmente recuperado em menos de três anos de vida útil do biodigestor. O VPL e a TIR na situação (c) estão acima das demais, o que expressa maior viabilidade para a situação onde a capacidade de utilização do biodigestor é maximizada.

No Tabela 15, estão expressos os resultados dos métodos de viabilidade analisados.

Tabela 15 - Análise de viabilidade para a primeira hipótese considerando os custos da propriedade analisada.

\begin{tabular}{|c|c|c|c|}
\hline Situação (plantel) & Payback & VPL & TIR \\
\hline Marujo: 850 matrizes; 665 terminados (a) & - & - $\mathrm{R} \$ 17.778,12$ & $7,27 \%$ \\
\hline $\begin{array}{l}\text { Granjas Jan: } 850 \text { matrizes; } 1900 \\
\text { terminados(b) }\end{array}$ & 4,253 & $\mathrm{R} \$ 199.036,21$ & $26,67 \%$ \\
\hline $\begin{array}{l}\text { Hipótese: } 1.218 \text { matrizes; } 2.630 \\
\text { terminados }(\mathrm{c})\end{array}$ & 2,770 & $\mathrm{R} \$ 388.328,20$ & $41,21 \%$ \\
\hline
\end{tabular}

Fonte: Resultado da pesquisa.

- Sumarização dos resultados da Primeira hipótese: custos do Paraná versus custos do Senhor Jan

No primeiro cenário trabalhado dentro da hipótese inicial, foi realizada uma análise generalizada para o Paraná. Da estimativa de custos realizada com base nos dados fornecidos pela CONAB por peso 
vivo de animal entregue ao mercado, foi retirado o custo e consumo médio de energia elétrica para o plantel de 1900 suínos.

No segundo cenário, os dados trabalhados foram os da Chácara pesquisada, que apresenta resultados diferenciados da média paranaense devido a fatores como: a produção de parte dos insumos; pagar salários maiores que a média paranaense aos seus funcionários; possuir mão de obra destinada à administração, dentre outros. Desta forma, o caso estudado não poderia servir de parâmetro isolado para análise paranaense com relação a custos e lucros. Portanto, foram realizadas simulações de ambos os casos para a produção de energia elétrica a partir do biogás e suas respectivas análises de viabilidade.

É importante notar que o consumo de energia elétrica da Chácara Marujo é maior que o consumo médio paranaense, no entanto, a agregação de renda que o Sr. Jan obtém com o biogás é menor, primeiro, porque a renda do produtor com a suinocultura é maior que a média dos produtores paranaense e, segundo, porque o preço pago pela energia elétrica pelo Senhor Jan também é menor que a da grande maioria dos suinocultores do Estado.

Desta forma, pegando o lucro que os suinocultores tendem a ter ao ano (Tabela 3) frente à receita líquida oriunda do uso do biodigestor (Tabela 11), tem-se a agregação de renda deste último na renda do suinocultor. O mesmo ocorre para Jan: pegando seu lucro anual (Tabela 4) frente à receita líquida obtida com o uso do biodigestor (Tabela 14), tem-se a agregação de renda que a transformação de dejetos gera para ele quando considerando a renda obtida com a suinocultura. Assim, verifica-se que a agregação de renda existe (Tabela 16) e ela é significativamente superior para os suinocultores do Paraná, de tal forma que, na situação (c), esta renda adicional chega a representar um incremento de quase $40 \%$ na renda do produtor ao ano.

Com relação à viabilidade econômica das diferentes situações trabalhadas, fica evidente que, tanto para o caso do Paraná, como para o caso do Sr. Jan, ao maximizar a capacidade dos biodigestores, o projeto torna-se extremamente viável, podendo o capital investido ser recuperado 
nos primeiros anos de vida útil do biodigestor e trazendo retornos de até quatro vezes a taxa mínima de atratividade. Isso demonstra que o superdimensionamento de um projeto pode atrapalhar a viabilidade do mesmo, em que, como a capacidade usada do biodigestor atual é de apenas $32,8 \%$, então, poderia se ter feito um investimento menor, obtendo a mesma receita e, ao mesmo tempo, tornando-o mais viável, cuja recuperação seria num tempo bem menor.

Tabela 16 - Análise de viabilidade para a primeira hipótese considerando os custos do Paraná versus da propriedade analisada.

\begin{tabular}{l|c|c|c|c|c|c|c|c}
\hline \multirow{2}{*}{\begin{tabular}{l} 
Situação (plantel) \\
\cline { 2 - 8 }
\end{tabular}} & \multicolumn{5}{|c|}{ Caso do Paraná } & \multicolumn{3}{c}{ Caso do Senhor Jan } \\
\cline { 2 - 9 } & Payback & VPL & TIR & $\begin{array}{c}\text { (\%) Renda } \\
\text { Adicionada }\end{array}$ & Payback & VPL & TIR & $\begin{array}{c}\text { (\%) Renda } \\
\text { Adicionada }\end{array}$ \\
\hline $\begin{array}{l}\text { Marujo: } 850 \\
\text { matrizes; } 665 \\
\text { terminados (a) }\end{array}$ & 9,589 & $6.244,31$ & $9,73 \%$ & $21,77 \%$ & - & $(17.778,12)$ & $7,27 \%$ & $6,27 \%$ \\
$\begin{array}{l}\text { Granjas Jan: } 850 \\
\text { matrizes; } 1900 \\
\text { terminados (b) }\end{array}$ & 4,774 & $160.719,56$ & $23,56 \%$ & $36,26 \%$ & 4,253 & $199.036,21$ & $26,67 \%$ & $12,81 \%$ \\
$\begin{array}{l}\text { Hipótese: } 1.218 \\
\text { matrizes; } 2.630 \\
\text { terminados (c) }\end{array}$ & 3,135 & $324.488,48$ & $36,43 \%$ & $37,29 \%$ & 2,770 & $388.328,20$ & $41,21 \%$ & $13,37 \%$ \\
\hline
\end{tabular}

Fonte: Resultado da pesquisa.

No entanto, ressalta-se novamente que, no caso paranaense, mesmo que não se esteja usando a capacidade máxima do biodigestor, a sua implantação é viável economicamente (pois o capital é recuperado antes do termino da vida útil do projeto; a TIR é maior que a taxa de atratividade e o VPL é positivo), trazendo uma agregação de renda significativa para a suinocultura. Haja vista que a suinocultura é uma atividade instável - por ser constantemente afetada pelo mercado externo e também pela cotação dos insumos derivados do meio agrícola - então, essa agregação de renda gerada pelo biodigestor pode também representar uma fonte de segurança para os produtores suinícolas, colaborando para a própria prosperidade da atividade, garantido renda para o meio rural. 


\subsubsection{Segunda Hipótese: caso prático Sr. Jan Haasjes}

No caso estudado, o biogás é comprimido e distribuído por toda a propriedade por um sistema de gasoduto composto por mais de 1.400 metros de cano PVC, sendo utilizado para diversas finalidades, como: aquecimento do piso das pocilgas e do escritório, em um sistema em que a água é aquecida em cadeiras a $40^{\circ} \mathrm{C}$ e mantida nesta temperatura, circulando por serpentinas abaixo do piso; utilizado nas cozinhas da propriedade em substituição a 15 botijões GLP ao mês; 4 chuveiros de aquecimento à gás; e utilizado também na secagem de grão em época de safra. Quando há excedente, o biogás é encaminhado para o motor gerador de energia elétrica, chamado de economizador de energia, por estar ligado diretamente na rede de distribuição da chácara.

- Receita

A renda gerada pela utilização do biogás, neste caso, é representada pela economia que o produtor obteve de gás GLP e energia elétrica. Antes da instalação dos biodigestores, o produtor já utilizava em sua propriedade o gás GLP para a secagem de grãos, na cozinha das casas da chácara e no aquecimento do piso de uma das pocilgas, que já era equipada com aquecedor de água e serpentinas. O consumo anual de gás era, em média, $17.850 \mathrm{Kg}$, o equivalente a aproximadamente $R \$ 49.980,00$, cotado a preços do primeiro semestre de 2012 , mais $R \$$ $585,00^{8}$ gastos com a compra de 15 botijões de $13 \mathrm{Kg}$ de gás GLP ao mês, destinado à cozinha das casas da Chácara.

O biogás produzido na Chácara Marujo é suficiente para atender totalmente a demanda de gás da propriedade, tornando, assim, estes $\mathrm{R} \$$ 50.565,00 anuais um incremento de renda não monetária.

A energia elétrica gerava para o produtor um custo mensal de $\mathrm{R} \$$ $5.760,00$, em média, (a preços atuais) antes da instalação do biodigestor. De acordo com os dados coletados na Chácara, no primeiro semestre de 2012 , o custo foi em torno de $\mathrm{R} \$ 2.568,20$, ou seja, houve uma economia de $\mathrm{R} \$ 3.191,80$ com energia elétrica, possibilitando uma renda não monetária anual de $\mathrm{R} \$ 38.301,60$. 
Desta forma, tem-se que a receita para o produtor oriunda da economia gerada pelo aproveitamento do biogás é num montante igual a $\mathrm{R} \$ 88.866,60^{9}$ anuais.

- Investimento

O custo que o Sr. Jan teve com a construção dos biodigestores, as adaptações, modificações e mão de obra necessária para a geração e aproveitamento do biogás foram detalhados na sessão 3.2 (Tabela $3.5)$, sendo o montante de $R \$ 412.400,00$ - valor a preço do primeiro semestre de 2012.

- Fluxo de caixa

O custo de manutenção mensal dos biodigestores é o mesmo estimado na sessão 3.3.1, ou seja, $R \$ 855,56$, dado que este é o custo real do produtor, estimado com dados do primeiro semestre de 2012. Assim, o custo anual de manutenção é $R$ \$ 10.266,72.

Tendo em vista que a vida útil do projeto é de 10 anos, o fluxo de caixa para este cenário é composto pelo investimento inicial de $R \$$ $412.400,00$ mais dez fluxos de $\mathrm{R} \$ 78.599,88$ positivos, calculados a partir das receitas não monetárias anuais e do custo manutenção anuais do biodigestor.

- Viabilidade do investimento

Na segunda hipótese, foi trabalhado apenas o caso do Sr. Jan Haasjes. Por este ser bem específico, é importante analisar se a viabilidade teórica do caso estudado traz os retornos constatados na prática, desta forma, foram eliminadas as situações (b) e (c).

Como mostra a tabela 17, o Payback calculado à taxa de desconto de $9,1 \%$ resultou em um tempo de retorno total do capital investido de menos de oito anos. O VPL do investimento tem valor positivo e uma Taxa Interna de Retono de 13,85\%, dados estes que apenas constatam a viabilidade já verificada pelo Sr. Jan Haasjes e apenas reafirmam o tempo de retorno do investimento informado pelo produtor. Essa viabilidade do investimento está sendo auferida com um uso muito 
pequeno da capacidade instalada do biodigestor, ou seja, utilizam-se de apenas $38 \%$ dessa capacidade. Assim, principalmente se o projeto não fosse tão superestimado, o investimento seria menor e tenderia a aumentar ainda mais a viabilidade do negócio. Ou, de outra maneira, se uma maior quantidade de dejetos de suínos fosse transformada nos biodigestores, aumentar-se-ia a receita e também haveria uma elevação nessa viabilidade. Nesta última possibilidade, ter-se-ia um aumento de produção de biogás, contudo, ainda existem outros usos na propriedade do senhor Jan para absorver esse excedente, principalmente no que se refere à substituição de energia elétrica externa, que atualmente a propriedade ainda é uma demandante.

Vale lembrar, ainda, que existem outros benefícios que não estão sendo aqui mencionados e que poderiam elevar ainda mais a viabilidade do negócio, como, por exemplo: diminuição do impacto ambiental ao se estar transformando os dejetos de suínos nos biodigestores; o atendimento à legislação ambiental, evitando multas; a melhoria do bemestar do produtor e da comunidade ao seu entorno, com a diminuição de odores, de moscas, etc. e a produção do biofertilizante, o qual pode ser aplicado ao solo, com uma redução bastante significativa de seu impacto ambiental, além do que muitos autores defendem que tal biofertilizante vem com eficiência maior do que a aplicação dos dejetos in natura no solo ${ }^{10}$.

Por fim, outro elemento importante apresentado na Tabela 17 refere-se à renda adicionada. Se pegar o lucro anual do senhor Jan (Tabela 4.4) frente à receita líquida obtida com o uso do biodigestor nesta segunda hipótese ( $R \$ 78.599,88)$, tem-se a agregação de renda que a transformação de dejetos gera para ele quando considerando a renda obtida com a suinocultura. Esta, de acordo com os dados, elevaria em $15 \%$, tornando-se importante principalmente para diminuir a vulnerabilidade do produtor dentro da cadeia produtiva. Isso porque os dejetos são um subproduto da atividade, então a sua transformação gera, de imediato, uma renda adicional bastante representativa, se considerar a renda líquida que o produtor obtém da atividade como um todo. 
Tabela 17- Análise de viabilidade para a segunda hipótese: uso atual do biogás da propriedade analisada.

\begin{tabular}{l|c|c|c}
\hline Payback & VPL & TIR & Renda Adicionada (\%) \\
\hline 7,463 & $\mathrm{R} \$ 89.814,40$ & $13,85 \%$ & $15,14 \%$ \\
\hline
\end{tabular}

Fonte: Resultado da pesquisa.

\section{Considerações finais}

O objetivo deste trabalho foi analisar a viabilidade econômica do uso de biodigestores na transformação de dejetos suínos. Com base nos resultados, constatou-se a viabilidade econômica em todas as situações, exceto na situação (a) do caso do Jan do primeiro cenário, em que são utilizados para análise o plantel atual do produtor e seus referidos custos, sendo transformado todo biogás em energia elétrica. Desta forma, conclui-se que para sua atual condição na suinocultura e capacidade utilizada do biodigestor de apenas $38,2 \%$, seria inviável para o Sr. Jan Haasjes utilizar todo o biogás produzido para a geração de energia elétrica (consumido parte e vendendo o restante).

No entanto, se elevar o uso dos biodigestores para $72,25 \%$, tal investimento já se torna viável economicamente (situação "b"), possibilitando o incremento de $37,29 \%$ na renda do produtor. Contudo, nota-se que na situação (c), ao maximizar a capacidade do biodigestor, a agregação de renda passa a representar apenas $1,03 \%$ a mais que na situação (b), isso porque, para maximizar o uso do biodigestor, seria necessário aumentar o plantel, assim, elevando a renda do produtor decorrente da suinocultura.

É importante ressaltar que a situação (a) feita para o caso do senhor Jan utiliza a mesma capacidade dos biodigestores que a segunda hipótese, na qual se avaliou o uso que atualmente está se fazendo do biogás produzido na propriedade. Em ambas, utilizam-se 38,2\% da capacidade. Porém, na segunda hipótese, está se usando o gás para diversos fins e o restante do biogás se transformando em energia elétrica. Neste cenário, o Payback, o VPL e a TIR demonstram viabilidade 
econômica do projeto e, além disso, a renda adicionada com o uso dos biodigestores (15\%) é maior que a obtida até mesmo nas situações (b) e (c), nas quais o uso dos biodigestores é aumentado substancialmente, obtendo, respectivamente, agregação de apenas 12,8\% e 13,4\%.

Ou seja, no caso específico do senhor Jan, com o uso atual dos dejetos (38,2\% para os biodigestores), a aplicação que se faz do biogás produzido está sendo eficiente, gerando viabilidade econômica para o investimento.

Por fim, com o objetivo de se ter um parâmetro para a suinocultura paranaense, considerando apenas a transformação do biogás em energia elétrica, é que se fez a primeira hipótese para o caso paranaense. Nela, verifica-se que se toda a capacidade instalada do biodigestor estivesse sendo utilizada, o investimento seria recuperado em menos de 4 anos, além do que a agregação de renda para o suinocultor seria de $37 \%$. Mesmo na situação em que apenas $38,2 \%$ da capacidade instalada dos biodigestores estivessem sendo utilizados, o investimento continuaria sendo viável, com uma renda adicionada para o suinocultor de aproximadamente $22 \%$. Neste sentido, como a suinocultura é uma atividade que nos últimos tempos vem passando por diversos desafios (principalmente, referente à vulnerabilidade do mercado, oscilação dos preços dos insumos), essa agregação de renda possibilitada pela transformação dos dejetos se torna importante até mesmo para diminuir os riscos da atividade.

Além disso, é importante lembrar que a legislação ambiental para a suinocultura no Paraná é bastante rígida com relação aos dejetos, tornando o manejo destes um inconveniente da atividade. Portanto, além do incremento constatado na renda do suinocultor, o biodigestor contribuiria para a diminuição dos impactos ambientais da atividade, melhorando até mesmo o bem-estar do produtor e de todo o entorno (com diminuição dos odores, de moscas, etc.). Todos esses benefícios não foram mensurados, no entanto é uma contribuição importante para o desenvolvimento sustentável da suinocultura, o que torna o investimento em biodigestores ainda mais atrativo. 
Igualmente, outro fator não considerado na análise é referente ao biofertilizante em que os resíduos da biodigestão se transformam, podendo ser aplicados diretamente no solo. O produtor estudado aplica em suas lavouras, além da adubação indicada pelo agrônomo, o biofertilizante. Segundo ele, obteve nas últimas safras o maior índice de produtividade da região, no entanto, antes do biodigestor, ele já utilizava os dejetos in natura para aplicação no solo. Desta forma, não se pode atrelar o ganho de produtividade apenas ao biofertilizante, tendo em vista que estudos da área comprovam que as moléculas dos dejetos in natura demoram mais tempo para serem quebradas, acarretando em resultados em longo prazo. Também, como não há estudos que indiquem o quanto aumenta a produtividade dada à aplicação de dejetos, além do que não se sabe o sentido do efeito que os dejetos têm sobre a produtividade (por exemplo, pode ser uma relação quadrática entre eles, onde no início a aplicação dos dejetos no solo gera um crescimento positivo da fertilidade, crescendo até determinado ponto - ponto de máximo -, a partir do qual pode ter efeitos negativos - como ocorre quando se aplica fertilizante industrial no solo de forma excessiva).

Por estes fatos, não foi considerado nesta análise o biofertilizante como incremento de renda. Contudo, sugere-se que pesquisas sejam feitas visando analisar a produtividade que se obtém com o uso de biofertilizantes versus dejetos in natura no longo prazo, para verificar se o uso do primeiro traz uma resposta mais positiva do que a aplicação direta dos dejetos no solo.

De forma geral, conclui-se neste trabalho que, além da diminuição dos impactos ambientais, do tratamento dos dejetos conforme determina a legislação, o biodigestor ainda possibilita agregação de renda significativa ao produtor e apresenta viabilidade econômica.

\section{Referências}

BUARQUE, C. Avaliação econômica de projetos. Rio de Janeiro: Campus, 1984. 
CADEIA produtiva de carne suína no Brasil. Disponível em: http://www. porkworld.com.br/artigos/post/a-cadeia-produtiva-da-carne-suina-nobrasil-_15105. Acesso em: 26 mar. 2012.

COLDEBELLA, A. Viabilidade do uso de biogás da bovinocultura e suinocultura para geração de energia elétrica e irrigação em propriedades rurais. 2006. 74 f. Dissertação (Mestrado em Engenharia da Produção). Universidade Estadual do Oeste do Paraná , Cascavel, PR, 2006.

COMPANHIA NACIONAL DE ABASTECIMENTO. Custos de produção. Disponível em: <http://www.conab.gov.br/conteudos.php?a=545\&t=2>. Acesso em: 30 jul. 2012.

DIESEL, R.; MIRANDA, C. R.; PERDOMO, C. Manejo de dejetos de suínos. Boletim Informativo de Pesquisa: BIPERS 14 - Embrapa Suínos e Aves. Emater. RS, 2002. Disponível em: http://docsagencia. cnptia.embrapa.br/ suino/bipers/bipers14.pdf. Acesso em: 30 jul. 2012.

GRANJA de suínos traz bons resultados. Gazeta Digital. 2010. Disponível em:<<http://www.gazetadigital.com.br/conteudo/show/ secao/14/materia/261283>. Acesso em: 30 jul. 2012

INSTITUTO BRASILEIRO DE GEOGRAFIA E ESTATÍSTICA. Disponível em: <http://www.ibge.gov.br/home/estatistica/indicadores/ agropecuaria/producaoagropecuaria/abate-leite-couro-ovos_201104_ publ_completa.pdf>. Acesso em: 15 jan. 2012.

MACHADO, M. G. Tratamento e aproveitamento dos dejetos suínos com ênfase na produção de biogás: estudo de caso: Suinutri Indústria e Comércio de Derivados de Carne LTDA. Campo Verde,MT: UNESC, 2009.

NOGUEIRA, L. A. H. Biodigestão: a alternativa energética. São Paulo: Nobel, 1986.

RANZI, T. J. D.; ANDRADE, M. A. N. Estudo de viabilidade de transformação de esterqueiras e bioesterqueiras para dejetos 
de suínos em biodigestores rurais visando o aproveitamento do biofertilizante e do biogás. In: ENCONTRO DE ENERGIA NO MEIO RURAL E GERAÇÃO DISTRIBUÍDA, 5., 2004, Campinas, SP. Anais... Campinas, SP, 2004. 1 CD-ROM.

RIBEIRO, F. S. R.; RAIHER, A. P.; MIRANDA, G. M. Potencial da geração de energia a partir dos dejetos gerados pela suinocultura no Estado do Paraná. In: CONGRESSO BRASILEIRO DE PLANEJAMENTO ENERGÉTICO, 8., Curitiba, 2012. Anais....Curitiba, 2012. 1 CD-ROM.

SINDICARNE. Cotações. Disponíveis em:<http://www.sindicarne.com. br/content/category/4/7/12/>. Acesso em: 30 jul. 2012.

SILVA, N.A. Construção e operação de biodigestor: modelo chinês: EMBRATER - manual técnico, Brasilía, DF: Embrater, 1983.

WALISIEWICZ, M. Energia alternativa. São Paulo: Publifolha, 2007. ZANETTE, A. L. Potencial de aproveitamento energético do biogás no Brasil. 2009. 105 f. Dissertação (Mestrado em Planejamento Energético)-Universidade Federal do Rio de janeiro, Rio de Janeiro, 2009.

Artigo recebido em: 04/02/2013

Aprovado em: 16/08/2013 